\title{
The Readiness of Geography Teachers to use Mobile devices in the Context of Immersive Technologies Integration into the Teaching Process
}

\author{
Ivan Stojšić A $^{*}$, Anđelija Ivkov-Džigurski ${ }^{A}$, Olja Maričić ${ }^{B}$ \\ Received: February 27, 2019 | Revised: May 28, 2019 | Accepted: June 03, 2019 \\ DOI: $10.5937 / g p 23-20762$
}

\begin{abstract}
The rapid development of immersive technologies has opened up the possibilities for using augmented, mixed, and virtual reality in education. The theoretical part of this paper included a literature review of previous studies dealing with the use of augmented and virtual reality in geography teaching and learning. However, a question raised regarding the readiness of geography teachers to integrate mobile devices and use the advantages of immersive technologies in practice. Based on their digital competences and readiness to use mobile devices and other information and communication technologies in the teaching process four groups of geography teachers can be separated using cluster analysis. The clusters are: 1) Confident and innovative, 2) Traditional approach, 3) Optimistic but low-digitally skilled, and 4) Pessimistic but digitally skilled teachers. Teachers (particularly those in the first cluster) highly assessed the possibilities of using immersive technologies in practice (especially with the physical and regional geography teaching contents).
\end{abstract}

Keywords: augmented reality; educational technology; geography teacher; geography teaching; immersive teaching; mobile learning; virtual reality

\section{Introduction}

Digital technologies are present today in almost all segments of everyday life (Livas et al., 2019) and influence the process of transformation of learning environments (Daniela, 2019). The tendency to base the contemporary initial didactic-methodical education, as well as the professional development of teachers, on the Technological Pedagogical Content Knowledge model (TPACK; Koehler et al., 2013; Mishra \& Koehler, 2006) is noticeable. This model relates to mutual integration and independence of three types of knowledge (content, pedagogical, and technology knowledge) and presents a standard framework for the implementation and successful use of educational technology in the teaching process (Bower et al., 2010). Romrell et al. (2014) emphasised that for the creation and evaluation of mobile learning activity (when mobile devices enable learning to be personalised, situated, and connected) the SAMR model (see Puentedura, 2013) can be particularly useful. However, in order to truly use the advantages that mobile and immersive technologies create, teaching activities need to be planned in such a manner that they surpass the first

\footnotetext{
A University of Novi Sad, Faculty of Sciences, Department of Geography, Tourism and Hotel Management, Trg Dositeja Obradovića 3, 21000 Novi Sad, Republic of Serbia,

email: ivan.stojsic@yahoo.com; ivan.stojsic@uns.ac.rs; andjelija.ivkov@dgt.uns.ac.rs

B University of Novi Sad, Faculty of Education in Sombor, 25000 Sombor, Podgorička 4, Republic of Serbia, email: olja.maricic@pef.uns.ac.rs

* Corresponding author: Ivan Stojšić; email: ivan.stojsic@yahoo.com, tel: +38162 206114
} 
level of the SAMR model (four levels of technology integration: S - substitution, A - augmentation, M modification, and $\mathrm{R}$ - redefinition) (Stojšić et al., 2019).

The meta-analysis that was conducted by Sung et al. (2016) showed that the application of mobile devices in education gave better effects than when desktop computers were used, as well as compared to not using any of those devices. However, it should be emphasised that the effects of mobile devices depend on the manner of their use in the classrooms and the possible negative impact on the learning outcomes may occur if those devices are used for activities unrelated to class lecture (Kuznekoff et al., 2015). In the last couple of years, a new paradigm called Smart pedagogy has been started to shape to meet the challenges and needs of the technology-enhanced learning (see Daniela, 2019).

Suh and Prophet (2018) pointed out that the notion of immersive technology could be defined from various aspects, but that it most frequently covers several different technologies, such as virtual (VR), augmented (AR), and mixed reality (MR). Also, the same authors stated that this term could be best understood through "virtuality continuum" (see Milgram
\& Kishino, 1994). Virtuality continuum begins with a real environment and ends in a completely virtual one. AR is closer to the real environment and together with augmented virtuality is a part of MR (Milgram \& Kishino, 1994). Shute et al. (2017) emphasised that the immersive technologies are becoming more and more available to educational institutions and that the immersive learning environments (with the use of AR, $\mathrm{VR}$, and digital games) enable an active learning approach (based on constructivist and situational learning theories). The focus of this paper is on the possibilities of AR and VR integration in geography teaching in the Republic of Serbia.

$\mathrm{AR}$ is a growing trend in the area of mobile learning (Fombona et al., 2017), while Cochrane (2016) pointed out the importance of smartphones for the implementation of immersive VR (IVR) in education. In accordance with that, the need to examine the readiness of the teachers to apply mobile devices in the teaching process imposed. Also, Graziano (2017) emphasised that the actual use of AR and VR is strongly related to the ability of teachers to integrate these technologies into their pedagogical practice.

\section{Theoretical background}

\section{AR in geography teaching and learning}

$A R$ can be defined as a spectrum of technologies that project various types of computer-generated materials (such as $3 \mathrm{D}$ models, text, images, video materials, sound, and animations) into user's perception of the real world (Bower et al., 2014; Yuen et al., 2011). The AR applications can be divided into two groups: marker or image-based (the device camera is used to transform the printed signal into virtual information) and marker-less or location-based (Carbonell Carrera et al., 2018; Cheng \& Tsai, 2013).

Yuen et al. (2011) emphasised five significant groups of AR application in education: AR books, AR gaming, discovery-based learning, objects modelling, and skills training. All five groups can be used in geography teaching. Besides textbooks (Figure 1), markerbased AR can be applied in workbooks, maps, blank maps, tests, posters, and similar. Alongside mark-

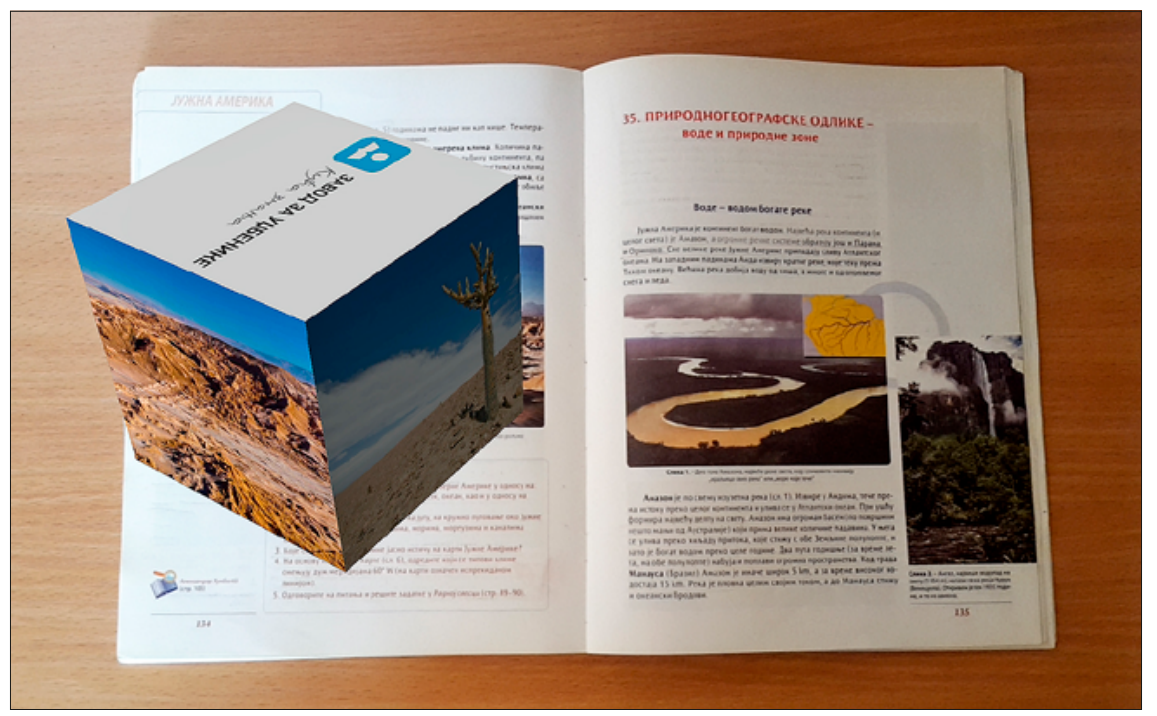

Figure 1. AR Android application for Geography textbook for the seventh grade of primary school Source: Tadić, 2016; Photo: Ivan Stojšić with the permission of Zavod za udžbenike, Belgrade 
ers, the marker-less AR technology based on the use of GPS-enabled mobile devices (such as smartphones and tablets) can be used in geography learning through games (such as geocaching), discovery-based learning, and geographical skills training (e.g., spatial reasoning and spatial orientation) (see Bursztyn et al., 2017; Carbonell Carrera \& Bermejo Asensio, 2017; Pombo et al., 2018). Also, this technology provides significant possibilities for modelling various geographic objects, phenomena, and processes, and for this purpose, the use of AR Sandbox can be particularly useful (see Vaughan et al., 2017; Woods et al., 2016).

Besides aforementioned, it should be noted that AR is useful to visualise GIS content (ARGIS; Kamel Boulos et al., 2017), as well as for urban planning and in the Smart City context (Ramos et al., 2018).

Numerous papers (from primary school to university level) showed positive effects of AR usage in motivating the students and for learning various geographic contents and skills, such as: astronomy and mathematical geography (Fleck et al., 2015; Shelton \& Hedley, 2002), cartography and spatial orientation and navigation (Carbonell Carrera \& Bermejo Asensio, 2017; Ramos et al., 2018), pedology, geology and geomorphology (Bursztyn et al., 2017; Carbonell Carrera et al., 2018; Vaughan et al., 2017; Woods et al., 2016), biodiversity, ecological awareness and conservation (Lin et al., 2011; Pombo et al., 2018), and cultural and historical heritage (Chang et al., 2015; Szymczyk et al., 2018).

\section{VR in geography teaching and learning}

VR is usually defined as a three-dimensional computer-generated environment, available in real time, and in compliance with user behaviour and interaction through different input/output devices (Boud et al., 1999). Additionally, VR can be described as a collection of various technologies (hardware and software) that deliver an immersive learning experience (Hussein \& Nätterdal, 2015).

There are two different categories of VR: "desktop" VR (DVR) or "through the window" VR (WVR) and IVR. DVR/WVR provides some limited level of immersion and requires the user to be positioned in front of a viewing device (i.e., computer monitor, tablet, smartphone, etc.). Interaction with DVR/WVR environments is possible through input devices, such as a keyboard and mouse, touch screen or controller. On the other hand, IVR environments can produce a sense of presence (or "being there" experience). Interaction with the immersive virtual environment is possible with specialised controllers, haptic devices and wearables, and motion and body tracking technology (Southgate et al., 2016).

Through the use of computers for games, simulations, and virtual worlds, DVR had already found a broader application in the teaching process. However, up until a couple of years ago, IVR had not been significantly used in formal education, primarily due to its high price and technology imperfection (Merchant et al., 2014). In literature, IVR is related to the use of Cave Automated Virtual Environment (CAVE) and various head-mounted displays (HMDs) (Southgate et al., 2016). According to Stojšić et al. (2019), new, improved, and widely available HMDs can be divided in several groups:

- PC/console-based headsets (Oculus Rift, HTC Vive, Windows Mixed Reality devices, PlayStation VR, etc.);

- Mobile-based headsets (such as Google Cardboardtype viewers, Daydream View, Samsung Gear VR, etc.);

- Standalone VR devices (Oculus Go, Lenovo Mirage Solo, ClassVR, and similar).

For geography, it is particularly important the use of VR together with GIS technologies (Figure 2) for the $3 \mathrm{D}$ visualisation and modelling, creating virtual geographic environments, and spatial planning and analytics (Batty et al., 2017; Huang et al., 2001).

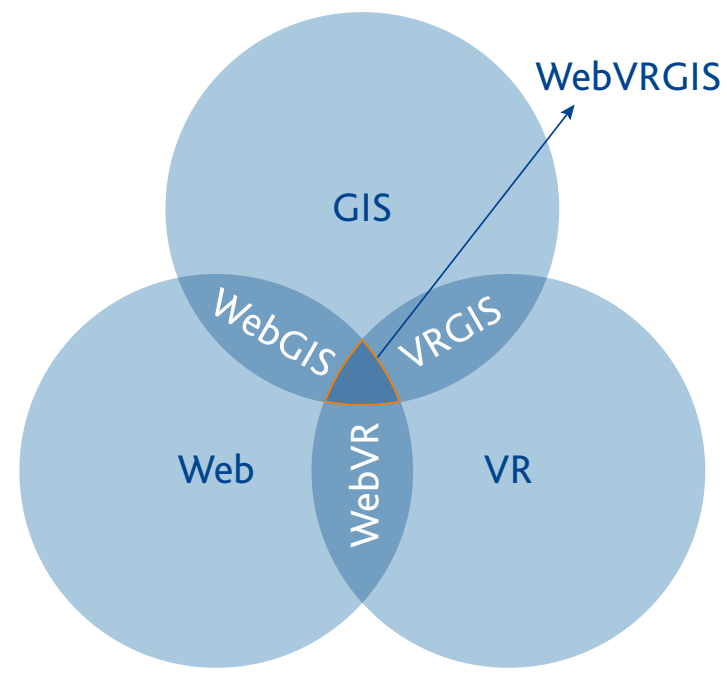

Figure 2. Relationship between VR, Web and GIS technologies

Source: Stojšić et al., 2018; based on: Huang et al., 2001

On the application of DVR/WVR (for simulations, digital games, and virtual worlds) in geography teaching and learning see List \& Bryant, 2014; Luo et al., 2016; and Tüzün et al., 2009.

Experimental studies (conducted on all levels of education) showed that IVR (with the use of HMDs) could have a positive influence on students' motivation and improve learning outcomes for various geographic contents and skills, such as: astronomy and mathematical geography (Hussein \& Nätterdal, 2015; Madden et al., 2018), cartography and spatial orienta- 
tion (Carbonell-Carrera \& Saorín, 2017; Šašinka et al., 2019), climate change and ecological awareness (Bailenson, 2018; Markowitz et al., 2018), physical, social and regional geography - virtual field trips (Minocha et al., 2017; Vishwanath et al., 2017).

More about when and how to use this technology in education, about ethical and safety issues and recommended time limit for the use of HMDs (up to 15 or 20 minutes) see Bailenson, 2018; Southgate et al., 2018; and Stojšić et al., 2019.

\section{Integration challenges and a BYOD initiative}

Gandolfi (2018) pointed out that the popularity of AR and VR are continuously increasing, but that these technologies are not always easily available to the majority of teachers. The same author emphasised that before implementation several issues related to costs, teacher's preparation, pedagogy, and content need to be considered. Additionally, Johnston et al. (2018, p. 415-416) noted that the knowledge of pedagogical foundations of VR applications (apps) could make a choice and integration easier, however, the purchase of HMDs may require "thousands or hundreds of thousands from institutional budgets".

Bring your own device (BYOD) is an alternative strategy for the integration of immersive technology where students bring their personal mobile devices to school to use them for learning activities. This approach can be practical for educational institutions that lack resources. The BYOD initiative affects the teaching process and changes students' behaviour. This change can be positive (improved and modernised learning), as well as negative (inappropriate use) (Livas et al., 2019). For more information on the process of BYOD implementation (setting clear rules, establishing communication of all stakeholders, etc.) see Ackerman \& Krupp, 2012; Livas et al., 2019; and Parsons \& Adhikari, 2016.

\section{Purpose and research questions}

This paper focused on five research questions (RQs) that emerged from the literature review.

The level of information and communication technology (ICT) equippedness, ownership of mobile devices by the teachers, and the regulations in primary and secondary schools in the Republic of Serbia vary significantly (Körösi \& Esztelecki, 2015; Stojšić et al., 2018). Therefore, the following questions could be raised:

RQ1: How available are computers and mobile devices to geography teachers?

RQ2: Do school regulations allow the use of mobile devices in teaching and learning processes?

RQ3: Do geography teachers use BYOD in teaching organisation and practice?

According to Mac Callum et al. (2014), teachers' intention to apply mobile technologies in practice depends on factors such as digital literacy, ICT anxiety, and teaching self-efficacy, as well as the perceived ease of use and usefulness of new technology. The aforementioned and similar factors may be included in the cluster analysis and based on that the fourth research question was formulated:

RQ4: How can geography teachers be grouped in clusters based on their readiness to apply mobile devices in teaching practice?

According to Bower and Sturman (2015), for teachers to use the possibilities of immersive technologies (the authors used the term "wearable technologies" having in mind Oculus Rift and Google Glass) to improve their classes, they first needed to recognise their affordances. Thus, the last research question was formulated as follows:

RQ5: How the teachers assess the possibilities of immersive technologies (AR and VR) for geography teaching, and are there statistically significant differences in assessment between separate clusters?

\section{Methodology}

\section{Sample and procedure}

The research's population included all primary and secondary geography teachers in the Republic of Serbia. A non-probability (voluntary) sampling method was used. Through three invitation cycles covering the period from the end of November 2017 to mid-April 2018 more than 350 geography teachers were invited by personalised emails or direct calls. Also, the invitation was distributed via social media groups dedicated to geography teachers. The teachers were not compensated for taking part in this research. However, a certificate of participation was provided.
The research had two parts. In the first one, the teachers were asked to observe the online presentation (created for the first author's doctoral thesis research) in order to acquire knowledge about AR and VR in geography teaching. The second part was filling in the questionnaire. In the end, answers from 106 geography teachers were gathered. Sample characteristics are shown in Table 1.

According to OECD (2019), in almost all European countries, the vast majority of primary and secondary school teachers are female. Most of the participants were female $(76.4 \%)$, which was expected since it is in line with similar research and general gender struc- 
Table 1. Descriptive characteristics of the sample

\begin{tabular}{|c|c|c|c|}
\hline \multicolumn{2}{|l|}{ Variable } & \multirow{2}{*}{$\begin{array}{r}\text { Frequency }(\mathrm{n}) \\
81\end{array}$} & \multirow{2}{*}{$\begin{array}{r}\text { Percentage (\%) } \\
76.4\end{array}$} \\
\hline Condor & female & & \\
\hline ventiven & male & 25 & 23.6 \\
\hline \multirow{3}{*}{ Age } & $\leq 35$ & 18 & 17.0 \\
\hline & $36-50$ & 67 & 63.2 \\
\hline & $\geq 51$ & 21 & 19.8 \\
\hline \multirow{7}{*}{$\begin{array}{l}\text { Teaching } \\
\text { experience }\end{array}$} & $\leq 5$ & 13 & 12.3 \\
\hline & $6-10$ & 20 & 18.9 \\
\hline & $11-15$ & 20 & 18.9 \\
\hline & $16-20$ & 27 & 25.5 \\
\hline & $21-25$ & 11 & 10.4 \\
\hline & $26-30$ & 12 & 11.3 \\
\hline & $\geq 31$ & 3 & 2.8 \\
\hline \multirow{3}{*}{$\begin{array}{l}\text { Employed in } \\
\text { (educational stage) }\end{array}$} & primary school(s) & 41 & 38.7 \\
\hline & secondary school(s) & 40 & 37.7 \\
\hline & $\begin{array}{l}\text { both (in primary and } \\
\text { secondary schools) }\end{array}$ & 25 & 23.6 \\
\hline \multirow{3}{*}{$\begin{array}{l}\text { Employed in } \\
\text { (place of school) }\end{array}$} & rural school(s) & 8 & 7.5 \\
\hline & urban school(s) & 74 & 69.8 \\
\hline & $\begin{array}{l}\text { both (in urban and } \\
\text { rural schools) }\end{array}$ & 24 & 22.6 \\
\hline \multirow{2}{*}{$\begin{array}{l}\text { Employed in } \\
\text { (type of school) }\end{array}$} & public & 102 & 96.2 \\
\hline & private & 4 & 3.8 \\
\hline
\end{tabular}

ture of geography teachers in the Republic of Serbia (see Ilić, 2014; Lukić et al., 2019). Geography teachers with various backgrounds were invited to participate in this research. However, it should be noted that the sample mostly consisted of digitally literate teachers; therefore, in comparison to the general population, technology competent teachers may have been overrepresented in the sample.

\section{Questionnaire design}

The constructed questionnaire consisted of four major parts.

The first part contained guidelines on how to fill in the questionnaire and questions that were related to demographic characteristics of geography teachers and their work experience.

The second part contained questions related to the ownership of mobile devices by teachers, the availability of school ICT equipment, as well as the extent of their application in teaching. The questions on the use of BYOD concept in practice, as well as teachers' selfevaluation on the development of their digital competencies (measured on a scale from 1 - undeveloped to 10 - fully developed), were also asked. The last part of this segment was 5-point Likert scale (from 1 - strongly disagree to 5 - strongly agree) constructed to measure teachers' readiness to use mobile devices in practice.
In constructing the scale items, the theoretical base was a Mobile Learning Readiness scale (MLR; Lin et al., 2016). The final scale contained 20 items (defined both as positive and negative statements) to measure teachers' readiness to use mobile devices in practice. Since the new items in the constructed scale were highly modified (and some very different from original), the appropriateness of the sample was checked for an exploratory factor analysis. The Kaiser-Meyer-Olkin value $(\mathrm{KMO}=.916)$ and the results of Bartlett's test of sphericity $\left(\chi^{2}=1427.54, p<.001\right)$ verified the sampling adequacy for the analysis (see Coakes, 2012). The principal component analysis with a direct oblimin rotation method was performed. As a result, 20 items were categorised under three factors accounting for $64.21 \%$ of the variance (Table 2 ).

The first factor (named "perceived usefulness and advantages") consisted of nine positive statements and one negative (the item score was reversed). The second factor (named "perceived self-efficacy") consisted of four positive items and one negative (this item score was reversed). The third factor (named "perceived disadvantages and limitations") consisted of five negative items (scores were not reversed).

Through the third and fourth part of the questionnaire, open and closed questions were asked related to the possibility of AR and VR application in geogra- 
Table 2. Results of principal component analysis with a direct oblimin rotation

\begin{tabular}{|c|c|c|c|}
\hline Items & Factor 1 & Factor 2 & Factor 3 \\
\hline 4. Mobile devices create possibilities of learning anywhere and anytime. & .88 & & \\
\hline $\begin{array}{l}\text { 16. The use of mobile devices makes communication and information distribution easier, } \\
\text { which is important in teaching. }\end{array}$ & .81 & & \\
\hline 7. Students can gain new knowledge and skills by using appropriate educational mobile apps. & .80 & & \\
\hline $\begin{array}{l}\text { 5. Examples of good practice of the use of mobile devices in geography teaching can improve } \\
\text { my work. }\end{array}$ & .78 & & \\
\hline 13. Mobile devices can improve the teaching process. & .77 & & \\
\hline 10. Smartphones and tablets are learning tools. & .77 & & \\
\hline 19. Using mobile apps makes geography classes more interesting to students. & .75 & & \\
\hline $\begin{array}{l}\text { 20. Students should bring their own mobile devices to school and use them in geography } \\
\text { classes. }\end{array}$ & .62 & & \\
\hline 1. The smartphone is a modern teaching mean. & 61 & & \\
\hline $\begin{array}{l}\text { *6. The integration of smartphones/tablets only unnecessarily complicates the teaching } \\
\text { process. }\end{array}$ & .57 & & \\
\hline $\begin{array}{l}\text { *11. I am not sufficiently familiar with the educational possibilities of mobile devices to use } \\
\text { them in classes. }\end{array}$ & & .84 & \\
\hline $\begin{array}{l}\text { 2. I am familiar with numerous mobile apps and online tools that can be used in geography } \\
\text { teaching. }\end{array}$ & & .75 & \\
\hline $\begin{array}{l}\text { 14. I am familiar with the advantages and disadvantages of mobile devices usage in } \\
\text { education. }\end{array}$ & & .70 & \\
\hline 8. I can successfully organize a class using mobile apps and online tools. & & .60 & \\
\hline 17. I use mobile devices successfully in my teaching practice. & & .43 & \\
\hline *15. Mobile devices are difficult to integrate into the teaching process. & & & .72 \\
\hline *3. Mobile devices have no place in classrooms. & & & .70 \\
\hline *18. Students do not know how to use mobile devices for learning. & & & .67 \\
\hline *9. Smartphone use in class only distracts students' attention from the teaching content. & & & .59 \\
\hline $\begin{array}{l}\text { *12. There are not sufficiently good apps and online contents to justify the use of } \\
\text { smartphones/tablets in geography classes. }\end{array}$ & & & .40 \\
\hline$\%$ of variance explained & 47.91 & 9.25 & 7.05 \\
\hline Cronbach's alpha value & .95 & .81 & .74 \\
\hline
\end{tabular}

Note: Factors comprised items with a factor loading greater than .40. The negative items have been reversed $\left({ }^{*}=\right.$ item with reverse coding).

phy education. This paper analysed just a fragment of these questions, only those that were related to teachers' assessment of the possibility of using these technologies in geography teaching: "Evaluate (from 1 - no to 10 - extraordinary possibility) the potential of the use of augmented/virtual reality in geography teaching and learning." and "Evaluate (from $1-n o$ to 5 extraordinary possibility) the possibilities of the use of augmented/virtual reality in teaching/learning: a) cartographic and GIS contents; b) mathematical geography contents; c) physical geography contents; d) social geography contents; and e) regional geography contents."

\section{Data analysis}

Descriptive statistics were used to answer the first three research questions. For the fourth question, a cluster analysis (hierarchical method with Ward's clustering algorithm; see Antonenko et al., 2012) was used, by which geography teachers were divided into groups based on the similarity of answers to five input variables: 1) perceived self-efficacy with mobile devices (measured with five items on a scale from 1 - completely disagree to 5 - completely agree), 2) perceived usefulness and advantages (measured with ten items on a scale from 1 - completely disagree to 5 - completely agree), 3) perceived disadvantages and limitations (measured with five items on a scale from 1 - completely disagree to 5 - completely agree), 4) selfreported development of digital competences (measured on a scale from 1 - undeveloped to 10 - fully developed), and 5) self-reported frequency of using ICT in teaching (measured on a scale: 1 - never; 2 - rarely [few times a year]; 3 - sometimes [about once a month]; 4 - often [every week]; and 5 - always [on every class]). The established clusters were used in the subsequent analysis to answer the fifth research question. For that purpose, non-parametric tests such as the Kruskal 
Wallis $H$ test and Mann-Whitney $U$ test were used, since the number of teachers in separate clusters was not equal and the dependent variables (assessments of the potential of AR and VR for geography education) deviated from the normal distribution. All analyses were done in IBM SPSS Statistics 21.

\section{Results}

The first research question analysed the availability of computers and mobile devices to geography teachers included in the research. The results showed that $50 \%$ of teachers had access to digital classrooms in their schools, while $71.7 \%$ had computers in geography classrooms (66\% also had Internet access). Fifteen teachers did not have access to digital classrooms nor computers. When it came to ownership of mobile devices, $87.7 \%$ had laptops and $85.8 \%$ smartphones, while only $34.9 \%$ of geography teachers owned a tablet. Only one teacher did not have any mobile devices, while $80.2 \%$ of teachers had two or more mobile devices.

The second research question analysed the teachers' answers related to school regulations on the use of mobile devices in classes. The teachers that worked in several schools gave the answers about the schools where they had the most classes. The results showed that $58.5 \%$ teachers worked in schools where school regulations forbade the use of mobile devices in classes, however, five teachers $(4.7 \%)$ reported that despite the regulations mobile devices could be used in practice without any problems. Only 18 teachers (17\%) worked in schools where the regulations allowed the use of these devices, while 26 teachers (24.5\%) worked in schools where this issue was not regulated.

The third research question dealt with the application of BYOD concept in practice and teachers' answers to the following question were analysed: "How often do you organise the classes in a way that the students use their mobile devices (smartphones, tablets or laptops)?" (Table 3).

Table 3 shows that $49.1 \%$ of teachers sometimes or often organised classes in a way that the students used their own mobile devices. Also, it could be noted that a significant number of teachers integrated BYOD despite the ban.

The fourth research question was related to the possibility of grouping similar geography teachers based on their readiness to use mobile devices in classes. The results of the hierarchical cluster analysis showed that a four-cluster solution was the most meaningful one (Table 4).

\section{The characteristics of four clusters are:}

Cluster 1 (Confident and innovative teachers) - included the teachers who reported a high level of perceived self-efficacy regarding the application of mobile

Table 3. Teachers' answers regarding the BYOD concept application

\begin{tabular}{|l|c|c|c|c|}
\hline $\begin{array}{l}\text { Mobile devices and BYOD } \\
\text { in school regulations }\end{array}$ & Never & $\begin{array}{c}\text { Rarely } \\
\text { (few times a year) }\end{array}$ & $\begin{array}{c}\text { Sometimes } \\
\text { (about once a month) }\end{array}$ & $\begin{array}{c}\text { Often } \\
\text { (every week) }\end{array}$ \\
\hline not allowed $(n=57)$ & $15(26.3 \%)$ & $18(31.6 \%)$ & $16(28.1 \%)$ & $8(14.0 \%)$ \\
\hline $\begin{array}{l}\text { not allowed, but tolerated in } \\
\text { practice }(n=5)\end{array}$ & $1(20 \%)$ & $1(20 \%)$ & $1(20 \%)$ & $2(40 \%)$ \\
\hline not regulated $(n=26)$ & $2(7.7 \%)$ & $9(34.6 \%)$ & $10(38.5 \%)$ & $5(19.2 \%)$ \\
\hline allowed $(n=18)$ & $1(5.6 \%)$ & $7(38.9 \%)$ & $5(27.8 \%)$ & $5(27.8 \%)$ \\
\hline Total: & $19(17.9 \%)$ & $35(33 \%)$ & $32(30.2 \%)$ & $20(18.9 \%)$ \\
\hline
\end{tabular}

Table 4. Means and standard deviations on clustering variables: Four-cluster solution

\begin{tabular}{|c|c|c|c|c|c|c|c|c|}
\hline \multirow{2}{*}{ Clustering variables } & \multicolumn{2}{|c|}{ Cluster $1, n=55$} & \multicolumn{2}{|c|}{ Cluster $2, n=16$} & \multicolumn{2}{|c|}{ Cluster $3, n=21$} & \multicolumn{2}{|c|}{ Cluster $4, n=14$} \\
\hline & $M$ & $S D$ & $M$ & $S D$ & M & $S D$ & $M$ & $S D$ \\
\hline Perceived self-efficacy & 4.09 & 0.49 & 2.72 & 0.57 & 3.05 & 0.60 & 3.04 & 0.56 \\
\hline $\begin{array}{l}\text { Perceived usefulness and } \\
\text { advantages }\end{array}$ & 4.46 & 0.45 & 3.44 & 0.48 & 4.00 & 0.31 & 2.90 & 0.86 \\
\hline $\begin{array}{l}\text { Perceived disadvantages } \\
\text { and limitations }\end{array}$ & 2.13 & 0.58 & 3.21 & 0.36 & 2.52 & 0.49 & 3.56 & 0.66 \\
\hline $\begin{array}{l}\text { Self-reported development } \\
\text { of digital competences }\end{array}$ & 8.25 & 1.11 & 6.25 & 1.24 & 4.86 & 0.91 & 7.93 & 1.21 \\
\hline $\begin{array}{l}\text { Self-reported frequency of } \\
\text { using ICT in teaching }\end{array}$ & 4.07 & 0.79 & 2.38 & 0.62 & 3.43 & 0.60 & 3.93 & 0.62 \\
\hline
\end{tabular}


devices in the teaching process, noticed their numerous benefits (and can handle their limitations), highly valued the level of development of their digital competencies and frequently used available ICTs in teaching.

Cluster 2 ("Traditional approach" teachers) - included the teachers who were insecure when it came to their perceived self-efficacy regarding mobile devices in the teaching process, also uncertain about the advantages and disadvantages of using these devices, reported medium level of development of digital competencies and rarely used the available ICTs in their teaching practice.

Cluster 3 (Optimistic but "low-digitally skilled" teachers) - included the teachers who were insecure when it came to their perceived self-efficacy, but agreed that there are significant benefits of the use of mobile devices (and limitations were not that big to prevent the application). However, they reported a low level of development of digital competencies, and only sometimes included ICTs in their teaching practice.

Cluster 4 (Pessimistic but "digitally skilled" teachers) - included the teachers who were unsure about their perceived self-efficacy with mobile devices and agreed that the limitations and obstacles of their use were larger than the benefits. However, they reported a high level of development of digital competencies and often used the available ICTs in practice.

The fifth research question was related to how the teachers evaluated the possibilities of immersive technologies, and to the assumption that defined clusters of teachers differently assessed the general potential of AR and VR in geography teaching and learning (Table 5) and their application during the realisation of various geographical contents (Table 6). The teachers did the evaluation after they had watched the online presentation about the application of AR/VR in education and geography teaching.

The teachers highly assessed the general possibilities of using $\operatorname{AR}(M=7.62, S D=1.75)$ and $\operatorname{VR}(M=7.98$, $S D=2.00$ ) in geography teaching. However, the results of Kruskal Wallis $H$ tests were statistically significant, which indicated that there were statistically significant differences between the clusters. The results of post hoc tests (Mann-Whitney $U$ tests with Bonferroni correction) revealed that, when it came to $\mathrm{AR}$, there was a sta-

Table 5. General teachers' assessment of the possibility of using AR/VR in geography teaching

\begin{tabular}{|c|c|c|c|c|c|c|c|}
\hline Perceived potential of & Cluster & $n$ & Median $(\bar{x})$ & M rank & Kruskal Wallis $\chi^{2}$ & $P$ & $\eta^{2}$ \\
\hline \multirow{4}{*}{ Augmented reality } & 1 & 55 & 9 & 65.39 & \multirow{4}{*}{19.164} & \multirow{4}{*}{$<.001$} & \multirow{4}{*}{.158} \\
\hline & 2 & 16 & 7 & 38.50 & & & \\
\hline & 3 & 21 & 8 & 46.45 & & & \\
\hline & 4 & 14 & 7 & 34.50 & & & \\
\hline \multirow{4}{*}{ Virtual reality } & 1 & 55 & 9 & 65.70 & \multirow{4}{*}{19.713} & \multirow{4}{*}{$<.001$} & \multirow{4}{*}{.162} \\
\hline & 2 & 16 & 7 & 35.38 & & & \\
\hline & 3 & 21 & 8 & 44.86 & & & \\
\hline & 4 & 14 & 8 & 39.25 & & & \\
\hline
\end{tabular}

Table 6. Geography teachers' assessment of the possibilities of using AR/VR with different teaching contents

\begin{tabular}{|c|c|c|c|c|c|c|c|c|c|c|c|c|}
\hline \multirow{2}{*}{\multicolumn{2}{|c|}{$\begin{array}{l}\text { Geographic teaching } \\
\text { content }\end{array}$}} & \multicolumn{2}{|c|}{$\begin{array}{c}\text { Cluster } 1 \\
n=55\end{array}$} & \multicolumn{2}{|c|}{$\begin{array}{c}\text { Cluster } 2 \\
n=16\end{array}$} & \multicolumn{2}{|c|}{$\begin{array}{c}\text { Cluster } 3 \\
n=21\end{array}$} & \multicolumn{2}{|c|}{$\begin{array}{c}\text { Cluster } 4 \\
n=14\end{array}$} & \multirow{3}{*}{$\begin{array}{l}\text { Kruskal } \\
\text { Wallis } \chi^{2}\end{array}$} & \multirow{3}{*}{$\begin{array}{c}P \\
.092\end{array}$} & \multirow{3}{*}{$\begin{array}{c}\eta^{2} \\
.059\end{array}$} \\
\hline & & \multirow{2}{*}{$\frac{\bar{x}}{4}$} & \multirow{2}{*}{$\begin{array}{l}\text { M rank } \\
59.59\end{array}$} & \multirow{2}{*}{\begin{tabular}{|r|}
$\bar{x}$ \\
3.5
\end{tabular}} & \multirow{2}{*}{$\begin{array}{l}\text { M rank } \\
41.94\end{array}$} & & \multirow{2}{*}{$\begin{array}{l}\text { M rank } \\
45.40\end{array}$} & \multirow{2}{*}{$\begin{array}{l}\bar{x} \\
4\end{array}$} & \multirow{2}{*}{$\begin{array}{l}\text { M rank } \\
54.93\end{array}$} & & & \\
\hline \multirow{5}{*}{$\begin{array}{l}\frac{a}{4} \\
\frac{1}{3} \\
\frac{+5}{3}\end{array}$} & Cartography and GIS & & & & & & & & & & & \\
\hline & $\begin{array}{l}\text { Mathematical } \\
\text { geography }\end{array}$ & 4 & 58.16 & 4 & 49.47 & 4 & 46.14 & 4 & 50.82 & 3.178 & .365 & .030 \\
\hline & Physical geography & 4 & 59.90 & 3.5 & 39.00 & 4 & 49.83 & 4 & 50.43 & 7.264 & .064 & .066 \\
\hline & $\begin{array}{l}\text { Social and cultural } \\
\text { geography }\end{array}$ & 4 & 58.41 & 4 & 44.38 & 4 & 50.02 & 4 & 49.86 & 3.819 & .282 & .036 \\
\hline & Regional geography & 4 & 58.85 & 4 & 42.31 & 4 & 49.48 & 4 & 51.29 & 4.979 & .173 & .047 \\
\hline \multirow{5}{*}{ 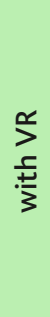 } & Cartography and GIS & 4 & 60.81 & 3 & 41.47 & 3 & 40.38 & 3.5 & 58.21 & 10.434 & .015 & .093 \\
\hline & $\begin{array}{l}\text { Mathematical } \\
\text { geography }\end{array}$ & 4 & 59.77 & 3 & 43.16 & 3 & 41.95 & 3.5 & 58.00 & 7.955 & .047 & .072 \\
\hline & Physical geography & 4 & 61.05 & 3 & 40.91 & 3 & 43.29 & 3.5 & 53.54 & 8.971 & .030 & .081 \\
\hline & $\begin{array}{l}\text { Social and cultural } \\
\text { geography }\end{array}$ & 4 & 60.27 & 3 & 44.31 & 3 & 43.79 & 3 & 51.96 & 6.949 & .074 & .064 \\
\hline & Regional geography & 4 & 60.95 & 3.5 & 46.47 & 3 & 42.05 & 3 & 49.43 & 7.843 & .049 & .071 \\
\hline
\end{tabular}


tistically significant difference between the first and the second cluster $(U=222.00, Z=-3.066, p=.002, r=$ -.364) and the first and the fourth cluster $(U=160.50, Z=$ -3.424, $p=.001, r=-.412$ ), while, when it came to VR, the statistically significant difference existed between the first and the second cluster $(U=195,50, Z=-3.461, p=$ $.001, r=-.412)$, the first and the third cluster $(U=354.00$, $Z=-2.675, p=.007, r=-.307)$ and the first and the fourth cluster $(U=182.00, Z=-3.125, p=.002, r=-.376)$.

The teachers saw the greatest possibility of using $\mathrm{AR}$ for teaching/learning physical geography $(M=$ 4.05, $S D=0.87)$ and regional geography contents $(M=$ $4.02, S D=0.80$ ). There were no statistically significant differences between separate clusters.
Also, when it came to VR, the teachers saw the most significant possibility of using this technology with physical geography $(M=3.65, S D=1.11)$ and regional geography teaching contents $(M=3.64, S D=1.06)$. The results of four out of five conducted Kruskal Wallis $H$ tests were statistically significant. However, the results of post hoc tests (Mann-Whitney U tests with Bonferroni correction) revealed that a statistically significant difference existed only between the first and the third cluster $(U=350.00, Z=-2.742, p=.006, r=$ -.315) when the possibility of application of VR technology with cartography and GIS contents was concerned.

\section{Discussion and Conclusion}

Innovative ICT should be used to induce a better understanding of geographical contents since they are necessary and crucial for living in a modern world (Tüzün et al., 2009). Shute et al. (2017) emphasised that immersive technologies can make the adoption of relevant competencies (knowledge, skills, and other attributes) easier in authentic environments and situations. VR and AR technologies can increase the obviousness and interestingness of geographical teaching contents, but the learning outcomes and standards should also be taken into account (Stojšić et al., 2018).

The results of this research showed that the majority of teachers had access to computers and mobile devices $(85.8 \%$ had access to digital classrooms or a computer in geography classroom and $99.1 \%$ of them owned at least one mobile device).

The majority of teachers $(58.5 \%)$ reported that school regulations were restrictive when it came to the use of mobile devices in classes. Such results showed that there is a need to regulate that issue differently since it leads to numerous contradictions. On one side, we are talking about the digital transformation of education and the integration of mobile and immersive technologies, and, on the other hand, they are "forbidden fruit". Also, regardless of the school regulations, the majority of teachers $(82.1 \%)$ reported that they used BYOD concept to organise their lessons, while $18.9 \%$ of teachers emphasised that they have been doing it often. The results of the qualitative research conducted by Stojšić et al. (2019) showed that the innovative and digitally competent teachers in the Republic of Serbia have successfully been using BYOD initiative for integration of immersive technologies into the teaching process.

By applying the hierarchical cluster analysis, the geography teachers were grouped into four clusters. The results were encouraging since the majority of teachers $(51.9 \%)$ were grouped in the first cluster that gath- ered digitally competent and innovative teachers (two teachers from this cluster reported already using IVR in classes with Google Cardboard HMDs). Other clusters indicated that there are teachers who need support and professional development programmes to improve their digital competencies. Graziano (2017) pointed out that it is necessary to prepare the pre- and in-service teachers for the use of immersive technologies in teaching. Also, teachers' networking should be supported for them to exchange examples of good practice.

The teachers (particularly those in the first cluster) evaluated highly the possibilities of using immersive technologies in practice, mostly with physical geography and regional geography programme contents. The pilot research conducted by Stojšić et al. (2018) showed that the teachers who applied ICTs in their teaching could successfully master the creation of content with VR technology using the Tour Creator authoring tool. However, Gandolfi (2018) emphasised that the immersive technologies are not suitable to be used only for "Wow" or novelty effects. The experiences from practice (contents that are difficult for students to acquire) and frequent students' misconceptions, present a good starting point in deciding when to use these technologies in geography teaching (Stojšić et al., 2018).

This research has several limitations. The questionnaire was based on the self-reported design; therefore, the level of development of teachers' digital competencies and the degree of application of ICTs and BYOD initiative in practice were not objectively measured. Besides, the sample of teachers was limited, and there is a possibility that those who participated were mainly the teachers with a developed digital competency.

There is a need for future research regarding the actual effects of the use of immersive technologies in geography teaching and learning, as well as to collect the examples of good practice. 


\section{References}

Ackerman, A. S., \& Krupp, M. L. (2012). Five components to consider for BYOT/BYOD. In D. G. Sampson, J. M. Spector, D. Ifenthaler, \& P. Isaías (Eds.), Proceedings of the IADIS International Conference on Cognition and Exploratory Learning in the Digital Age - CELDA 2012 (pp. 35-41). Madrid: IADIS Press. Retrieved from https://files.eric.ed.gov/fulltext/ED542652.pdf

Antonenko, P. D., Toy, S., \& Niederhauser, D. S. (2012). Using cluster analysis for data mining in educational technology research. Educational Technology Research and Development, 6o(3), 383-398. doi:10.1007/ s11423-012-9235-8

Bailenson, J. (2018). Experience of demand: What virtual reality is, how it works, and what it can do. New York: W. W. Norton \& Company.

Batty, M., Lin, H., \& Chen, M. (2017). Virtual realities, analogies and technologies in geography. In B. Warf (Ed.), Handbook on Geographies of Technolo$g y$ (pp. 96-110). Cheltenham: Edward Elgar Publishing Limited. doi:10.4337/9781785361166.00013

Boud, A. C., Haniff, D. J., Baber, C., \& Steiner, S. J. (1999). Virtual reality and augmented reality as a training tool for assembly tasks. In E. Banissi, F. Khosrowshahi, M. Sarfraz, E. Tatham, \& A. Ursyn (Eds.), Proceedings of the 1999 IEEE International Conference on Information Visualization: An International Conference on Computer Visualization \& Graphics (pp. 32-36). Los Alamitos: IEEE. doi:10.1109/IV.1999.781532

Bower, M., Hedberg, J. G., \& Kuswara, A. (2010). A framework for Web 2.0 learning design. Educational Media International, 47(3), 177-198. doi:10.1080/o 9523987.2010.518811

Bower, M., Howe, C., McCredie, N., Robinson, A., \& Grover, D. (2014). Augmented reality in education cases, places and potentials. Educational Media International, 51(1), 1-15. doi:10.1080/09523987.2014.88 9400

Bower, M., \& Sturman, D. (2015). What are the educational affordances of wearable technologies? Computers \& Education, 88, 343-353. doi:10.1016/j.compedu.2015.07.013

Bursztyn, N., Shelton, B., Walker, A., \& Pederson, J. (2017). Increasing undergraduate interest to learn geoscience with GPS-based augmented reality field trips on students' own smartphones. GSA Today, 27(6), 4-10. doi:10.1130/GSATG304A.1

Carbonell Carrera, C., \& Bermejo Asensio, L. A. (2017). Landscape interpretation with augmented reality and maps to improve spatial orientation skill. Jour- nal of Geography in Higher Education, 41(1), 119-133. doi:10.1080/03098265.2016.1260530

Carbonell-Carrera, C., \& Saorín, J. L. (2017). Geospatial Google Street View with virtual reality: A motivational approach for spatial training education. ISPRS International Journal of Geo-Information, 6(9):261. doi:10.3390/ijgi6090261

Carbonell Carrera, C., Saorin Perez, J. L., \& Torre Cantero, J. D. L. (2018). Teaching with AR as a tool for relief visualization: Usability and motivation study. International Research in Geographical and Environmental Education, 27(1), 69-84. doi:10.1080/ 10382046.2017.1285135

Chang, Y.-L., Hou, H.-T., Pan, C.-Y., Sung, Y.-T., \& Chang, K.-E. (2015). Apply an augmented reality in a mobile guidance to increase sense of place for heritage places. Journal of Educational Technology \& Society, 18(2), 166-178.

Cheng, K.-H., \& Tsai, C.-C. (2013). Affordances of augmented reality in science learning: Suggestions for future research. Journal of Science Education and Technology, 22(4), 449-462. doi:10.1007/s10956-0129405-9

Coakes, S. J. (2012). SPSS version 20.0 for Windows: Analysis without anguish. Milton: Wiley.

Cochrane, T. (2016). Mobile VR in education: From the fringe to the mainstream. International Journal of Mobile and Blended Learning (IJMBL), 8(4), 446o. doi:10.4018/IJMBL.2016100104

Daniela, L. (2019). Smart pedagogy for technologyenhanced learning. In L. Daniela (Ed.), Didactics of Smart Pedagogy: Smart Pedagogy for Technology Enhanced Learning (pp. 3-21). Cham: Springer. doi:10.1007/978-3-030-01551-0_1

Fleck, S., Hachet, M., \& Bastien, J. M. C. (2015). Marker-based augmented reality: Instructional-design to improve children interactions with astronomical concepts. In M. Umaschi Bers \& G. Revelle (Eds.), Proceedings of IDC 2015 - The 14th International Conference on Interaction Design and Children (pp. 21-28). New York: ACM. doi:10.1145/2771839.2771842

Fombona, J., Pascual-Sevillana, M.-A., \& GonzálezVidegaray, M. (2017). M-learning and augmented reality: A review of the scientific literature on the WoS repository. Comunicar, 25(52), 63-72. doi:10.3916/C52-2017-06

Gandolfi, E. (2018). Virtual reality and augmented reality. In K. Kennedy \& R. E. Ferdig (Eds.), Handbook of Research on K-12 Online and Blending Learning (2nd edition) (pp. 545-561). Pittsburgh: Carnegie Mellon University - ETC Press. 
Graziano, K. J. (2017). Immersive technology: Motivational reactions from preservice teachers. Internet Learning, 6(1), 33-58. doi:10.18278/il.6.1.4

Huang, B., Jiang, B., \& Li, H. (2001). An integration of GIS, virtual reality and the Internet for visualization, analysis and exploration of spatial data. International Journal of Geographical Information Science, 15(5), 439-456. doi:10.1080/13658810110046574

Hussein, M., \& Nätterdal, C. (2015). The benefits of virtual reality in education: A comparison study (BSc thesis). University of Gothenburg, Chalmers University of Technology, Göteborg, Sweden. Retrieved from http://hdl.handle.net/2077/39977

Ilić, T. (2014). Samovrednovanje kao instrument stručnog usavršavanja nastavnika geografije u Srbi$j i$ [Self-evaluation of geography teachers as a tool in in-service teacher training in Serbia] (Doctoral dissertation). University of Novi Sad, Faculty of Sciences, Novi Sad, Republic of Serbia. (in Serbian)

Johnston, E., Olivas, G., Steele, P., Smith, C., \& Bailey, L. (2018). Exploring pedagogical foundations of existing virtual reality educational applications: A content analysis study. Journal of Educational Technology Systems, 46(4), 414-439. doi:10.1177/0047239517745560

Kamel Boulos, M. N., Lu, Z., Guerrero, P., Jennett, C., \& Steed, A. (2017). From urban planning and emergency training to Pokémon Go: Applications of virtual reality GIS (VRGIS) and augmented reality GIS (ARGIS) in personal, public and environmental health. International Journal of Health Geographics, 16:7. doi:10.1186/s12942-017-0o81-0

Koehler, M. J., Mishra, P., \& Cain, W. (2013). What is technological pedagogical content knowledge (TPACK)? Journal of Education, 193(3), 13-19.

Körösi, G., \& Esztelecki, P. (2015). Implementation of mobile phones in education. Research in Pedagogy, 5(1), 98-108. doi:10.17810/2015.08

Kuznekoff, J. H., Munz, S., \& Titsworth, S. (2015). Mobile phones in the classroom: Examining the effects of texting, Twitter, and message content on student learning. Communication Education, 64(3), 344365. doi:10.1080/03634523.2015.1038727

Lin, H.-C. K., Hsieh, M.-C., Wang, C.-H., Sie, Z.-Y., \& Chang, S.-H. (2011). Establishment and usability evaluation of an interactive AR learning system on conservation of fish. Turkish Online Journal of Educational Technology-TOJET, 10(4), 181-187.

Lin, H.-H., Lin, S., Yeh, C.-H., Wang, Y.-S. (2016). Measuring mobile learning readiness: Scale development and validation. Internet Research, 26(1), 265-287. doi:10.1108/IntR-10-2014-0241

List, J., \& Bryant, B. (2014). Using Minecraft to encourage critical engagement of geography concepts. In M. Searson \& M. Ochoa (Eds.), Proceedings of
SITE 2014 - Society for Information Technology \& Teacher Education International Conference (pp. 2384-2388). Jacksonville: AACE.

Livas, C., Katsanakis, I., \& Vayia, E. (2019). Perceived impact of BYOD initiatives on post-secondary students' learning, behaviour and wellbeing: The perspective of educators in Greece. Education and Information Technologies, 24(1), 489-508. doi:10.1007/ s10639-018-9791-6

Lukić, A., Ivanović Bibić, L., Đukičin Vučković, S., Milanković Jovanov, J., Ivkov-Džigurski, A., \& Konečnik Kotnik, E. (2019). The role of homeroom - and geography teachers in the obligatory administration in elementary schools. Journal of the Geographical Institute "Jovan Cvijić" SASA, 69(1), 67-74. doi:10.2298/IJGI1901067L

Luo, W., Pelletier, J., Duffin, K., Ormand, C., Hung, W.-C., Shernoff, D. J., ... Furness, W. (2016). Advantages of computer simulation in enhancing students' learning about landform evolution: A case study using the Grand Canyon. Journal of Geoscience Education, 64(1), 60-73. doi:10.5408/15-080.1

Mac Callum, K., Jeffrey, L., \& Kinshuk (2014). Factors impacting teachers' adoption of mobile learning. Journal of Information Technology Education: Research, 13, 141-162. doi:10.28945/1970

Madden, J. H., Won, A. S., Schuldt, J. P., Kim, B., Pandita, S., Sun, Y., ... Holmes, N. G. (2018, August). Virtual reality as a teaching tool for Moon phases and beyond. Paper presented at the Physics Education Research Conference 2018, Washington, DC. doi:10.1119/perc.2018.pr.Madden

Markowitz, D. M., Laha, R., Perone, B. P., Pea, R. D., \& Bailenson, J. N. (2018). Immersive virtual reality field trips facilitate learning about climate change. Frontiers in Psychology, 9:2364. doi:10.3389/fpsyg.2018.02364

Merchant, Z., Goetz, E. T., Cifuentes, L., Keeney-Kennicutt, W., \& Davis, T. J. (2014). Effectiveness of virtual reality-based instruction on students' learning outcomes in $\mathrm{K}-12$ and higher education: $\mathrm{A}$ meta-analysis. Computers \& Education, 70, 29-40. doi:10.1016/j.compedu.2013.07.033

Milgram, P., \& Kishino, F. (1994). A taxonomy of mixed reality visual displays. IEICE Transactions on Information and Systems, E77-D(12), 1321-1329.

Minocha, S., Tudor, A.-D., \& Tilling, S. (2017). Affordances of mobile virtual reality and their role in learning and teaching. In L. Hall, T. Flint, S. O'Hara, \& P. Turner (Eds.), Proceedings of the 31st International BCS Human Computer Interaction Conference. Swindon: BCS Learning and Development. doi:10.14236/ewic/HCI2017.44

Mishra, P., \& Koehler, M. J. (2006). Technological pedagogical content knowledge: A framework for 
teacher knowledge. Teachers College Record, 108(6), 1017-1054.

OECD. (2019). Women teachers (indicator). doi:10.1787/ eeg64f55-en

Parsons, D., \& Adhikari, J. (2016). Bring your own device to secondary school: The perceptions of teachers, students and parents. The Electronic Journal of e-Learning (EJEL), 16(1), 66-80.

Pombo, L., Marques, M. M., Carlos, V., Guerra, C., Lucas, M., \& Loureiro M. J. (2018). Augmented reality and mobile learning in a smart urban park: Pupils' perceptions of the EduPARK game. In Ó. Mealha, M. Divitini, \& M. Rehm (Eds.), Proceedings of the 2nd International Conference on Smart Learning Ecosystems and Regional Development - Citizen, Territory and Technologies: Smart Learning Contexts and Practices (SIST, volume 80, pp. 90-100). Cham: Springer. doi:10.1007/978-3-319-61322-2_9

Puentedura, R. R. (2013). SAMR: Moving from enhancement to transformation. Retrieved from http://www. hippasus.com/rrpweblog/archives/2013/05/29/ SAMREnhancementToTransformation.pdf

Ramos, F., Trilles, S., Torres-Sospedra, J., \& Perales, F. J. (2018). New trends in using augmented reality apps for smart city contexts. ISPRS International Journal of Geo-Information, 7(12):478. doi:10.3390/ ijgi7120478

Romrell, D., Kidder, L. C., \& Wood, E. (2014). The SAMR model as a framework for evaluating mLearning. Journal of Asynchronous Learning Networks, 18(2). doi:10.24059/olj.v18i2.435

Šašinka, Č., Stachoň, Z., Sedlák, M., Chmelík, J., Herman, L., Kubíček, P., ... Juř́ik, V. (2019). Collaborative immersive virtual environments for education in geography. ISPRS International Journal of GeoInformation, 8(1):3. doi:10.3390/ijgi8010003

Shelton, B. E., \& Hedley, N. R. (2002, September). Using augmented reality for teaching Earth-Sun relationships to undergraduate geography students. Paper presented at The First IEEE International Augmented Reality Toolkit Workshop, Darmstadt, Germany. doi:10.1109/ART.2002.1106948

Shute, V., Rahimi, S., \& Emihovich, B. (2017). Assessment for learning in immersive environments. In D. Liu, C. Dede, R. Huang, \& J. Richards (Eds.), Virtual, Augmented, and Mixed Realities in Education (pp. 71-87). Singapore: Springer. doi:10.1007/978981-10-5490-7_5

Southgate, E., Smith, S. P., \& Cheers, H. (2016). Immersed in the future: A roadmap of existing and emerging technology for career exploration (DICE Report Series No. 3). Newcastle: DICE Research. Retrieved from http://dice.newcastle.edu.au/ DRS_3_2016.pdf
Southgate, E., Smith, S. P., Eather, G., Saxby, S., Cividino, C., Bergin, C., ... Scevak, J. (2018, March). Ethical conduct and student safety in immersive virtual reality: Protocols and resources from the VR School Research Project. Paper presented at the 2018 IEEE VR Third Workshop on K-12+ Embodied Learning through Virtual \& Augmented Reality (KELVAR), Reutlinger, Germany. Retrieved from https://vrschoolresearch.files.wordpress.com/2018/04/southgate-et-al-kelvar2018_prepub-version.pdf

Stojšić, I., Ivkov-Džigurski, A., \& Maričić, O. (2019). Virtual reality as a learning tool: How and where to start with immersive teaching. In L. Daniela (Ed.), Didactics of Smart Pedagogy: Smart Pedagogy for Technology Enhanced Learning (pp. 353-369). Cham: Springer. doi:10.1007/978-3-030-01551-0_18

Stojšić, I., Maričić, O., Ivkov Džigurski, A., \& Višnić, T. (2018). WebVR kao mogući konceptualni pristup za primenu virtuelne realnosti u nastavi geografije [WebVR as a possible conceptual approach for the application of virtual reality in geography teaching]. In J. Stanisavljević (Ed.), Zbornik radova - III didaktička konferencija predmetne didaktike: Unapređenje nastavnog procesa - prednosti i izazovi (pp. 81-94). Belgrade: The Serbian Society of Subject Didacticians. (in Serbian)

Suh, A., \& Prophet, J. (2018). The state of immersive technology research: A literature analysis. Computers in Human Behavior, 86, 77-90. doi:10.1016/j. chb.2018.04.019

Sung, Y.-T., Chang, K.-E., \& Liu, T.-C. (2016). The effects of integrating mobile devices with teaching and learning on students' learning performance: A meta-analysis and research synthesis. Computers \& Education, 94, 252-275. doi:10.1016/j.compedu.2015.11.008

Szymczyk, T., Montusiewicz, J., \& Skulimowski, S. (2018). An educational historical game using virtual reality. In L. Gómez Chova, A. López Martínez, \& I. Candel Torres (Eds.), INTED2018 Proceedings - 12th International Technology, Education and Development Conference (pp. 5964-5971). Valencia: IATED Academy. doi:10.21125/inted.2018.1412

Tadić, M. (2016). Geografija za sedmi razred osnovne škole. Beograd: Zavod za udžbenike. (in Serbian)

Tüzün, H., Yılmaz-Soylu, M., Karakuş, T., İnal, Y., \& Kizilkaya, G. (2009). The effects of computer games on primary school students' achievement and motivation in geography learning. Computers \& Education, 52(1), 68-77. doi:10.1016/j.compedu.2008.06.008

Vaughan, K. L., Vaughan, R. E., \& Seeley, J. M. (2017). Experiential learning in soil science: Use of an augmented reality sandbox. Natural Sciences Education, 46(1):160031. doi:10.4195/nse2016.11.0031 
Vishwanath, A., Kam, M., \& Kumar, N. (2017). Examining low-cost virtual reality for learning in low-resource environments. In O. Mival, M. Smyth, \& P. Dalsgaard (Eds.), Proceedings of the 2017 ACM Conference on Designing Interactive Systems - DIS'17 (pp. 1277-1281). New York: ACM. doi:10.1145/3064663.3064696

Woods, T. L., Reed, S., Hsi, S., Woods, J. A., \& Woods, M. R. (2016). Pilot study using the augmented reali- ty sandbox to teach topographic maps and surficial processes in introductory geology labs. Journal of Geoscience Education, 64(3), 199-214. doi:10.5408/15135.1

Yuen, S. C.-Y., Yaoyuneyong, G., \& Johnson, E. (2011). Augmented reality: An overview and five directions for AR in education. Journal of Educational Technology Development and Exchange, 4(1), 119140. doi:10.18785/jetde.0401.10 